\title{
Giant Buschke-Lowenstein tumour: clinical appraisal of a rare entity
}

\author{
Manish Garg, ${ }^{1}$ Vishwajeet Singh, ${ }^{1}$ Manoj Kumar, ${ }^{1}$ Satyanarayan Sankhwar ${ }^{2}$
}

${ }^{1}$ Department of Urology, King George Medical University, Lucknow, Uttar Pradesh, India ${ }^{2}$ Department of Urology, CSM Medical University (Upgraded KGMC), Lucknow,

Uttar Pradesh, India

\section{Correspondence to} Dr Manish Garg, dr_manugarg@yahoo.co.in

\section{DESCRIPTION}

A 52-year-old man, chronic smoker presented with a condition of a large, painless, foul-smelling mass in his penis of about 2 years. On detailed history, the patient revealed that in spite of applying various non-specific ointments and creams, the growth was gradually increasing in size. On physical examination, a large, exophytic, variegated growth measuring $10 \mathrm{~cm}$ at the largest diameter with papillary multilobulated surface was evident (figure 1). Some areas showed necrotic and ulcerated friable areas (figure 2). The growth entirely covered the glans, corona and some part of the distal penile shaft with sideways extension (figure 3). Surprisingly in spite of such large growth, the inguinal lymph nodes were not enlarged on palpation. Distant metastasis were excluded on the basis of chest radiography and $\mathrm{CT}$ of the abdomen. Preoperative biopsy revealed a condyloma acuminatum without malignancy or atypia. Partial penectomy was performed. The patient continued to be monitored at the outpatient clinic and did not have any evidence of recurrence and metastasis at 3 months of follow-up.

The Buschke-Löwenstein tumour, first described in 1948 by Ackerman in the oral cavity, ${ }^{1}$ is a rare but interesting low-grade penile tumour whose exact incidence is not known. Although characteristically locally very aggressive tumour, the regional lymph node and distant metastasis has yet not been reported. ${ }^{2}$ Tumour invades and destroys adjacent tissues and may involve the urethra. Microscopically, penile verrucous carcinoma is a very well-differentiated papillary neoplasm with

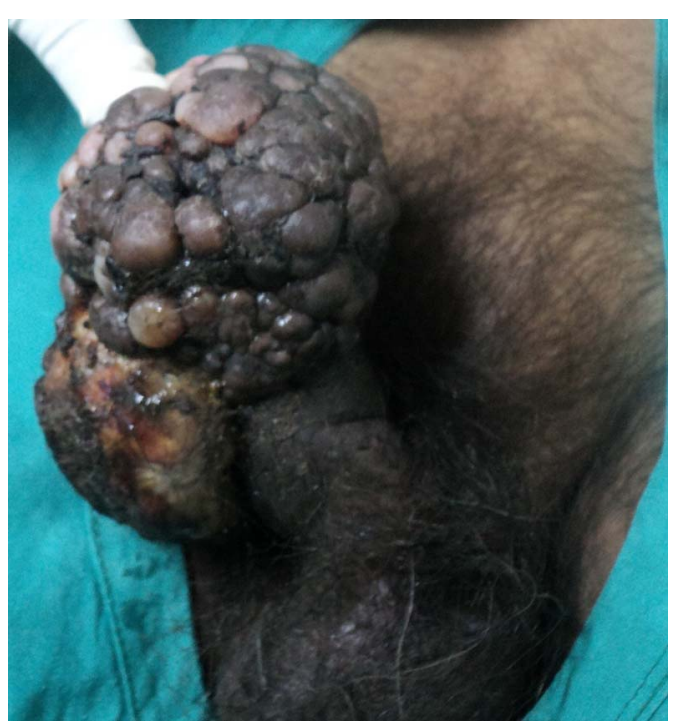

Figure 1 Buschke-Lowenstein tumour showing papillary multilobulated surface.

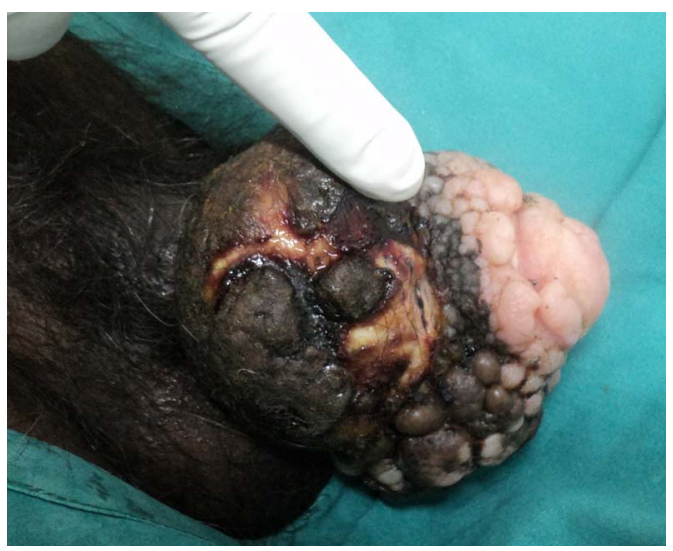

Figure 2 Tumour showing necrotic and ulcerated areas.

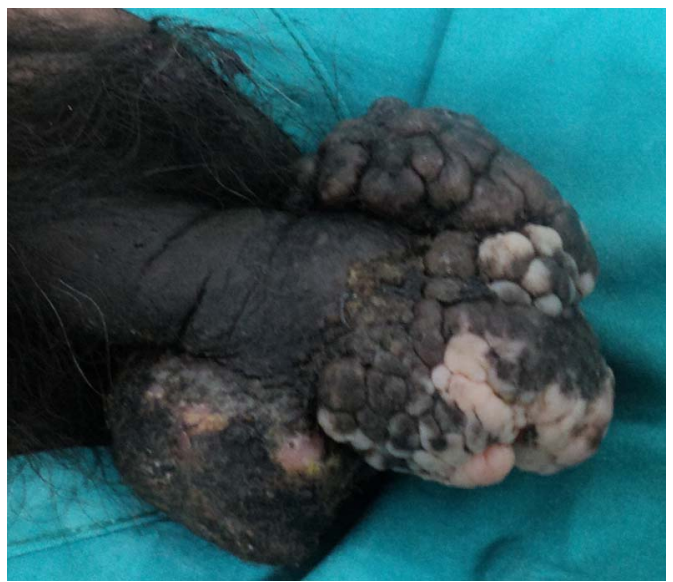

Figure 3 Tumour with sideways extension.

acanthosis and hyperkeratosis. Radiotherapy is ineffective and lesion may be managed with surgical excision.

\section{Learning points}

- Diagnosis of verrucous carcinoma should always be kept in mind while dealing with large penile growths.

- In spite of their significant local destructive appearance, these tumours are generally innocuous and have a low rate of lymph node and distant metastasis.

- Treatment consists of excision, sparing as much of the penis as possible. 
Contributors All authors contributed to the conception and design of the manuscript, helped in the analysis and interpretation of data, drafting the article for important intellectual content and approved the final version of the manuscript.

Competing interests None.

Patient consent Obtained.

Provenance and peer review Not commissioned; externally peer reviewed.

\section{REFERENCES}

1 Ackermann LV. Verrucous carcinoma of the oral cavity. Surgery 1948;23:670-8.

2 Stankiewicz E, Kudahetti SC, Prowse DM, et al. HPV infection and immunochemical detection of cell-cycle markers in verrucous carcinoma of the penis. Mod Pathol 2009;22:1160-8.

Copyright 2013 BMJ Publishing Group. All rights reserved. For permission to reuse any of this content visit http://group.bmj.com/group/rights-licensing/permissions.

BMJ Case Report Fellows may re-use this article for personal use and teaching without any further permission.

Become a Fellow of BMJ Case Reports today and you can:

- Submit as many cases as you like

- Enjoy fast sympathetic peer review and rapid publication of accepted articles

- Access all the published articles

- Re-use any of the published material for personal use and teaching without further permission

For information on Institutional Fellowships contact consortiasales@bmjgroup.com

Visit casereports.bmj.com for more articles like this and to become a Fellow 